\title{
Multipurpose optimization of canola oil deodorization parameters and evaluation of linolenic acid isomerization kinetics during pilot-scale deodorization
}

\author{
Onur Özdikicierler ${ }^{1}$, Fahri Yemiş̧̧ioğlu ${ }^{1}$, Nevin Başaran ${ }^{2}$, and Ferda Önen ${ }^{2}$ \\ ${ }^{1}$ Ege University \\ ${ }^{2}$ Besler Gıda ve Kimya San. ve Tic. A.Ş.
}

May 5, 2020

\begin{abstract}
In this study neutralized and bleached canola oil, deodorized according to the Central Composite Design consisting 30 experiments with differing levels of deodorization temperature, pressure, stripping steam rate and time parameters. Free fatty acid (FFA) content, oxidation stability index (OSI), peroxide value (PV), total polar compounds (TPC), tintometric redness, fatty acid composition of every deodorized canola oil sample was measured. Deodorization parameters were optimized using only responses with good model fit by aiming lowest free fatty acid and trans-linolenic acid (tr-C18:3) contents and highest OSI value and polyunsaturated fatty acid (PUFA) content via Response Surface Methodology. Optimum temperature, pressure, stripping steam, and time were predicted as $228.8^{\circ} \mathrm{C}, 1.4 \mathrm{mBar}, 1.25 \mathrm{gr} / \mathrm{min}$ and 80 minutes, respectively and the optimization model has predicted the FFA level to be $0.044 \%$, OSI as $10.65 \mathrm{~h}$, tr-C18:3 content as $0.21 \%$ and PUFA content as $30.50 \%$. Results of the validation experiments at this optimum point were close to the those predicted and the relative differences between predicted and validation results were within the variance coefficients of each model. Temperature and time of deodorization were found significantly effective on trans isomerization of linolenic acid on ANOVA, therefore the reaction rate constants of tr-C18:3 formation and cis-linolenic acid (cis-C18:3) degradation were calculated together with Arrhenius' equation constants using graphical method. Cis-C18:3 degradation rate was higher than that of tr-C18:3 formation showing; besides isomerization, different decomposition mechanisms took place for possibly not only for linolenic acid but also for all polyunsaturated fatty acids of canola oil during deodorization.
\end{abstract}

\section{Keywords}

Canola oil, deodorization, response surface methodology, optimization, linolenic acid, isomerization, Arrhenius' equation

\section{Introduction}

Vegetable oils are mainly composed of triglycerides and minor components such as mono- and diglycerides, phospholipids, tocopherols, sterols, phenolic compounds and coloring bodies. Most vegetable oils should be refined using chemical and physical methods before marketing mostly due to increase the acceptance by the consumer. Refining operation is generally applied to eliminate or reduce the content of the unwanted substances from vegetable oils such as free fatty acids, phospholipids, coloring bodies, odoriferous matters and oxidation products. Especially in deodorization step of the refining, which is a physical operation, most 
of the odoriferous materials, free fatty acids and possible contaminants such as PAH's and pesticides are being vaporized and removed with steam distillation principles. However, high temperatures up to approximately $240^{\circ} \mathrm{C}$, may induce unwanted chemical reactions such as geometrical isomerization or conjugation of unsaturated fatty acids, formation of glycidyl esters (GE), 3-monochloropropane 1-2- diol (3-MCPD) and possible loss of bioactive and nutraceutical compounds.

The optimization of refining steps according to the effects of process parameters on the minor components and quality parameters of different vegetable oil has been discussed and investigated widely in previous studies (Suliman et al., 2013; Yoon, 2016). In previous studies, optimization of refining conditions to reduce the formation of toxic contaminants such as 3-MCPD and GE in palm oil and olive oil has been studied (Özdikicierler et al., 2016; Zulkurnain et al., 2013). Since the elevated temperatures applied at deodorization cause a decrease in bioactive compounds such as tocopherols, sterols and phenolic compounds, optimization of the refining conditions to reduce the detrimental effect of refining has been discussed in several studies (Ceriani et al., 2008; Liu et al., 2019; Marangoni et al., 2019; Pan et al., 2019; Xie et al., 2019). Trans isomerization occurred during deodorization is another important issue investigated in many studies (Ceriani and Meirelles, 2007; Hénon et al., 1999; Kemény et al., 2001). Moreover, in another study the deodorizer designs were simulated at varying processing conditions and the effects on bioactive components and final oil quality has been discussed (Ceriani and Meirelles, 2004).

In general, Response Surface Methodology (RSM) was used in almost all above mentioned optimization studies, to develop mathematical models to explain the relationship between refining conditions and chemical composition of resulting refined oil and optimization of the parameter levels using a desirability function in accordance with determined targets. RSM is a statistical technique for designing experiments, building models, evaluating the effect of factors and searching optimum conditions for desirable responses. The optimization procedure involved systematic formulations design to minimize the number of experiments, and analyze the response surfaces in order to realize the effect of causal factors and to obtain the appropriate formulations with target goals as well as the acceptable component region as process control conditions in practical preparation (Deshmukh and Naik, 2015; Silbir et al., 2014).

Due to the chemical kinetics, vegetable oils rich in monounsaturated and polyunsaturated fatty acids are more vulnerable at high temperatures to isomerization than those rich in saturated fatty acids. Trans isomers of linoleic acid account for $0.2-1.0 \%$ of total fatty acids while trans isomers of linolenic acid may add up to $3 \%$ in commercial soybean and canola oils. Deodorization time and temperature have the most important role on the extent of trans isomer formation and kinetic measurements concerning geometrical isomerization of linolenic acid showed that the reaction is a first-order one and that the isomerization constant varies with temperature according to Arrhenius' law (Hénon et al., 1999). Trans isomerization or degradation of $\alpha$-linoleic and linolenic acids, associated with unpleasant "bad-cheese" odor, frequently mentioned in literature and industry at heated refined canola or rapeseed oil, is basically an indication of n- 6 or n-3 polyunsaturated fatty acid (PUFA) isomerization and linolenic acid decomposition (Ceriani and Meirelles, 2007; Ghazani et al., 2013; Hénon et al., 1999; Sghaier et al., 2016).

This study focused on determination of the effects and modeling of the pilot-scale deodorization process parameters of canola oil. Optimum deodorization temperature, pressure, stripping steam rate and deodorization time were determined and verified using Response Surface Methodology (RSM) to obtain a deodorized canola oil with high oxidation stability and PUFA content. Also, trans isomerization of linolenic acid, of which volatile oxidation products were associated with fish-like odor when oil is heated, discussed in detail during deodorization using reaction rates, activation energies and Arrhenius equation constants.

\section{Material and Method}

Crude canola oil was obtained from a local crude oil supplier. All processes and experiments were carried out in the research and development center of Besler Gıda ve Kimya San. ve Tic. A.Ş. which is a commercial 
vegetable oil refinery and industrial fat producer located in İstanbul, Turkey. Before deodorization, crude canola oil was neutralized using alkaline solution until FFA was decreased under $0.1 \%$ which is a typical target value for oil refinery at $85^{\circ} \mathrm{C}$ using $0.1 \%$ phosphoric acid and $48 \% \mathrm{NaOH}$. After neutralization, neutralized canola oil was bleached at $90^{\circ} \mathrm{C}$ for 30 min and under a vacuum of 70-80 mbar using acid-activated bleaching earth at 0.5-1.0\% of canola oil. The bleached canola oil was stored for deodorization experiments in a well-sealed stainless-steel tank and the headspace of the tank was substituted with nitrogen.

\section{Chemical Analyses}

Free fatty acid (FFA) content was measured by titration of the FFA in the sample with ethanolic potassium hydroxide solution according to the AOCS method Ca 5a-40 and express as percentages. Peroxide values (PV) were determined with titration of the oxidized potassium iodide using sodium thiosulphate and results were represented as milliequivalents of peroxide per kilograms of oil according to the AOCS method Cd 8b-90. In order to measure total polar compounds (TPC), oil samples were separated by column chromatography into nonpolar and polar compounds, followed by the elution of the nonpolar compounds. The polar compounds were determined by weight difference between the test sample and eluted nonpolar fraction according to the AOCS method Cd 20-91. Fatty acid compositions of oil samples were determined according to the AOCS method Ce 1a-13. The fatty acid methyl esters (FAME) of the sample obtained with cold methylation were separated on a capillary gas-liquid chromatography column having a highly polar stationary phase, according to chain length, degree of unsaturation, and geometry and position of the double bonds. Oxidation stability index (OSI) was measured using Rancimat 742 (Metrohm, USA) as the oxidation induction period of samples at $110^{\circ} \mathrm{C}$ according to AOCS method Cd 12b-92. In order to determine OSI, a stream of air was bubbled into oil samples placed in an electric heating block and formed volatile organic acids were collected in a measuring vessel containing distilled water. The electrical conductivity of the water was measured continuously as oxidation proceeded. Redness values are the tintometric red values measured with AOCS Tintometer with $\frac{1}{4}$ " cell (Lovibond, UK) according to the AOCS method Cc 13e-92. Each chemical used in analyses was obtained from Merck at suitable purity levels. All analyses were duplicated, and measurements were triplicated to ensure the accuracy of the results.

\section{Deodorization of Canola Oil}

Prior to the deodorization experiments initial FFA content, OSI, PV, TPC, tintometric redness and fatty acid composition were determined which are mentioned and discussed under the Results and Discussion in detail.

Deodorization experiments were carried out using a double jacket L822 model pilot-scale deodorizer tank with a batch capacity of 50L (Desmet Ballestra, Belgium) equipped with an ES630 model oil liquid vacuum pump (EDWARDS, Sweden) and E-1500A-2-0-30000-v6 model steam generator that produces dry superheated steam with adjustable rate (Cellkraft, Sweden). Eventually; 30L of neutralized and bleached canola oil was transferred to deodorizer, system pressure was decreased, temperature of the oil in deodorizer increased and maintained at the desired temperature using a programmable interface controller according to the experimental design. Deodorization duration was determined as the time that canola oil was retained in the desired deodorization temperature and referred as "deodorization time" in our article. Oil entrainment in overhead vapor was minimized by a large de-entrainment zone. The stripped odoriferous material with the fatty acids was condensed in the surface of the condenser item, which was cooled by a tempered water pump. The samples were after each deodorization experiment and stored under $-40^{\circ} \mathrm{C}$ until analyses. FFA content, OSI, PV, TPC, Redness and fatty acid composition were determined for every deodorized canola oil sample according to the experimental plan. 


\section{Experimental design and statistical analysis}

The experimental plan consists of 30 deodorization runs with changing levels of deodorization temperature, pressure, stripping steam rate and time which was developed by using Central Composite Design for four independent variables with three levels according to RSM. The upper and lower limits of these three independent variables of the steam distillation process and complete experimental design were given in Table

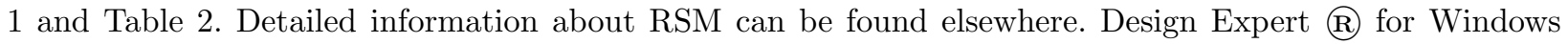
version 11.0 (StatEase, Inc., Minneapolis, MN, USA) was used for statistical evaluation and modeling with a second-order polynomial equation to determine the coefficients of the response model as well as their standard errors and significance.

Response models were as shown in Eq 1.

Eq $1 Y=\beta_{0}+\sum_{j=1}^{k} \beta_{j} X_{j}+\sum_{j=1}^{k} \beta_{\mathrm{jj}} X_{j}^{2}+\sum \sum_{i<j} \beta_{\mathrm{ij}} X_{i} X_{j}$

$\mathrm{Y}$ is the predicted response, $\beta_{0}, \beta_{\mathrm{i}}, \beta_{\mathrm{ii}}, \beta_{\mathrm{ij}}$ are the regression coefficients for the intercept and the linear, quadratic and interaction coefficients, respectively, $X_{i}$ and $X_{j}$ are independent variables and $k$ is the number of independent variables (Myers et al., 2011). Models were reduced from quadratic degree and highly insignificant coefficients $(\alpha>0.1)$ were eliminated using the back-substitution method.

Numerical optimization was applied to determine optimum temperature, stripping steam rate, pressure and time of steam distillation. Predicted values by RSM were validated by repeating the steam distillation operations at optimum conditions.

For linolenic acid, the isomerization constants followed according to Arrhenius' law and the natural logarithm of the equation which is a linear function was used to calculate the activation energy $\left(E_{a}\right)$ for isomerization. Arrhenius' law was given in Eq 2 where $k$ is rate constant, $A$ is preexponential factor, $T$ is the absolute temperature in kelvin, $E_{a}$ is the activation energy and $R$ is the universal gas constant equal to $8.314 \times 10^{11}$ J.K $\mathrm{K}^{-1} \cdot \mathrm{mol}^{-1}$

Eq 2. $k=A \bullet e^{-\frac{E a}{\mathrm{RT}}}$

Taking the natural logarithm of Arrhenius' equation gives linear function of natural logarithm of $k$ with respect to reciprocal of $T$ (Eq 3 ) which makes possible to calculate reaction constants ( $A$ and $E_{a}$ ) via graphical method.

Eq 3. $\ln k=\ln A-\frac{-E_{a}}{R} \bullet \frac{1}{T}$

\section{Results and Discussion}

Deodorization is the final step of vegetable oil refining where the aim is to eliminate or reduce undesired flavor from vegetable oil according to steam distillation principles with the help of stripping steam (Shahidi, 2005). Since, during deodorization, vegetable oil undergo elevated temperatures, strong vacuum and stripping steam, elimination of FFA, oxidation products and a significant degree of thermal decomposition of carotenoids is also expected (Suliman et al., 2013).

\section{Modeling the effect of deodorization parameters on deodorized canola oil quality characteristics}

Table 2 represents FFA content, OSI, PV, TPC and redness results of deodorized canola oil samples in our study together with the initial values of canola oil before deodorization experiments which was indicated in the first line. The FFA content was $0.071 \%$ initially since an alkaline neutralization was applied and apparently deodorization operations did not cause a significant reduction in FFA in our study. In general, FFA contents of deodorized canola oils were differed between $0.04 \%$ and $0077 \%$. Similar FFA level was 
measured as $0.05 \%$ and $0.02 \%$ at before and after deodorization of soybean oil in a factory scale deodorizer (Xie et al., 2019). OSI is the induction period for lipid oxidation at $110^{\circ} \mathrm{C}$ and simply calculated from the electrical conductivity curve of the heated sample (Oxidation stability of oils and fats - Rancimat method, 2016). OSI is a measure of oxidative stability which depend on mainly saturation level of the oil. Besides, if the antioxidative bioactive constituent content of oil increase, the OSI is expected to be lower. Although high temperatures cause a decrease in such bioactive compounds, OSI has increased or not changed significantly after deodorization of canola and soybean oils in previous studies (Farhoosh et al., 2009; Suliman et al., 2013; Xie et al., 2019). According to our results, the OSI values increased with the deodorization of canola oil from $7.5 \mathrm{~h}$ to between $9.5 \mathrm{~h}$ and $11.3 \mathrm{~h}$. This increase was observed because of the elimination of the oxidation products due to their small molecular weight and deaeration of the oil. Therefore, the oxidative stability of deodorized oil is not expected be lower than neutralized, bleached or winterized oil (Farhoosh et al., 2009; Xie et al., 2019).

Crude oils usually have higher PV content than the refined oil. The oxidation products accumulate in crude oils under the influence of oxidation reaction which may be induced with presence of light, content of trace metals, such as copper or iron (Kreps et al., 2014). Deodorization is a significant step of vegetable oil refining since not only undesired odoriferous material stripped away from the oil but also oxidative products, light molecular weighted contaminants and free fatty acids are being eliminated via steam stripping (De Greyt, 2012; Ortega-García et al., 2006). Therefore, a significant decrease in PV's was observed with deodorization from $3.4 \mathrm{meqO}_{2} / \mathrm{kg}$ oil to around 0 to $0.63 \mathrm{meqO}_{2} / \mathrm{kg}$ in all deodorization experiments, and PV of deodorized canola oil samples at 21 out of 30 experiments were measured as zero. As a comparison with laboratory scale deodorization, $\mathrm{PV}$ of kenaf seed oil has decreased from $1.24 \mathrm{meqO}_{2} / \mathrm{kg}$ to $0.55 \mathrm{meqO}_{2} / \mathrm{kg}$ with the laboratory scale deodorization, similarly, in a previous study (Chew et al., 2016).

The polar fraction is considered is the composition of oxidative products, therefore the higher the TPC content is, the lower the expected quality of the oil. Hence, the oils rich in PUFA such as soybean and canola oils are expected to be at similar quality according to TPC. During refining, a decrease in TPC after the neutralization is mainly due to the decrease in the contents of the FFA than in the contents of the other polar compounds. More significant decreases in the MG, DG and FFA during the deodorization step is expected to cause an additional decrease in TPC (Ruiz-Méndez et al., 1997). On the contrary, TPC was measured around $5.5 \%$ in deodorized canola oils while the initial TPC was $5.0 \%$, representing a slight increase at some experiments during deodorization in our study. Similarly, during deodorization at $230^{\circ} \mathrm{C}$, TPC of soybean and canola oils slightly increases from $5.92 \%$ to $6.06 \%$ and $4.12 \%$ to $5.33 \%$, respectively in a previous study (Farhoosh et al., 2009). Fournier et al. reported that polymerization accelerates in fish oil during deodorization at a temperature above $220^{\circ} \mathrm{C}$, where total polar fraction increased from $51.0 \mathrm{mg} / \mathrm{g}$ oil to $194.9 \mathrm{mg} / \mathrm{g}$ oil, when the deodorization temperature increased to $220^{\circ} \mathrm{C}$ to $250^{\circ} \mathrm{C}$ (Fournier et al., 2006). This may explain the slight and insignificant increase in TPC at deodorization experiments in our study, since the temperature of deodorization was differed between $220^{\circ} \mathrm{C}$ and $230^{\circ} \mathrm{C}$ in experimental plan.

The color bodies in oils include the carotenes, which gives yellow and red colors to the oil, are widely distributed in fats and oils, and are heat sensitive substances (Brien et al., 2000). Redness that was measured as either 1.9 or 2 or 2.1 while the initial redness level was 3.4. Apparently, the deodorization operation was caused a further decrease in redness because of the degradation of carotenoids at elevated temperatures of deodorization which is known as thermal bleaching (Joaquín et al., 2013). In a previous study, during deodorization redness of palm oil has reduced from around 3.2 to 1.1 (Zulkurnain et al., 2013). The decrease in carotenoids was also reported in hazelnut oil deodorization from $0.47 \mathrm{mg} / \mathrm{kg}$ oil to $0.33 \mathrm{mg} / \mathrm{kg}$ oil (Durmaz and Gökmen, 2019).

Although FFA content of deodorized canola oils differed between $0.04 \%$ and $0.077 \%$ while OSI was between 9.5 and 11.3 in many levels, PV, TPC and redness did not vary among all experiments. Therefore, mathematical modeling of PV, TPC and redness was not possible because of the lack of signal for this data. Mathematical models for FFA and OSI were developed by reducing quadratic model terms by excluding the ones that $\mathrm{p}$-values higher than 0.1. Temperature, pressure, stripping steam rate and time always kept 
in models even if their p-values were higher than 0.1 to maintain the logical expression capability of the developed model (Özdikicierler et al., 2016; Zulkurnain et al., 2013). ANOVA results together with the fit statistics of reduced quadratic models of FFA and OSI were given in Table 3.

The Model F-values of FFA and OSI were 28.90 and 41.05 imply the models were significant whereas the Lack of Fit F-values of those were 0.56 and 0.78 respectively implies that the lack of fit is not significant relative to the pure error and the models were well fitted to data. P-values less than 0.05 indicate model terms are significant. FFA content were significantly affected from the changes in temperature, pressure and stripping steam rate while time was not an effective parameter of FFA content of deodorized canola oil in this study. All the basic deodorization parameters were effective on OSI together with temperature - pressure and temperature - stripping steam interactions. As for the model fit statistics, $\mathrm{R}^{2}$ is a statistical measure of how close the data are to the fitted regression line whereas adjusted $R^{2}$ is the corrected $R^{2}$ value with number of model terms. As insignificant model terms are being added to model, $\mathrm{R}^{2}$ of the model increases while adjusted $\mathrm{R}^{2}$ value decreases. Predicted $\mathrm{R}^{2}$ is an indicator to understand how well the model predicts a response value. Therefore, the gap between predicted $\mathrm{R}^{2}$ and adjusted $\mathrm{R}^{2}$ are expected to be low $(<0.2)$ for models having a good predictive sufficiency (Balasubramani et al., 2015; Myers et al., 2011). Adequate precision (APrec) measures the signal to noise ratio of which value greater than 4 is desirable (Myers et al., 2011). In this case, for FFA and OSI models, adjusted $R^{2}$ were 0.85 and 0.89 while predicted $R^{2}$ values were 0.8 and 0.85 respectively. It was visualized in the Figure1a that the predicted values by FFA model has a good agreement with actual values of FFA and only a few data point has considerable residual. Cook's distance is a measure of how much the regression changes if the datum is deleted. Relatively large values can be associated with high leverage and large studentized residual. In another word, Cook's distances given in Figure1b illustrates that the importance of an individual FFA value on the FFA model structure. Although, FFA results of run 11 and 24 gave a Cook's distance 0.26 and 0.48 respectively, which was a relatively higher value than of other measurements, no FFA result was identified as outlier at Cook's distance plot when the significance level of $\alpha=0.05$, indicated as red line, was considered. All parameters except time has been found as effective on final FFA content of deodorized canola oil and, direction of these effects can be seen on Figure1c and Figure1d. The inversely proportional effect of striping steam on FFA content was found to be superior among all factors because of its high F-value. As the deodorization temperature increased, FFA content reduced. The effect of pressure o FFA content was not found to be linear since highest FFA contents were observed at medium pressure levels (around 2.2mbar) of our study. As the pressure increased to 3 or reduced to 1.4, the FFA content of deodorized oils were decreased. Although deodorization time was statistically effective in our study, in a previous study deodorization temperature and time were addressed as the most effective parameters on FFA content of deodorized oil however, deodorization experiments were carried out using laboratory scale deodorizer at 4mbar, on the contrary larger deodorizer was used at maximum 3mbar pressure in our study and differences in the equipment and methodology may be the reason (Suliman et al., 2013). In addition, Ceriani et al. discussed the differences in results of previous studies with theirs and reported that the variations in the results may be high with batch lab-scale deodorizer and pilot scale of full scale deodorizers, and indicated the difficulties in the model developing for lab-scale deodorizer conditions (Ceriani et al., 2008).

The fit statistics of OSI model had better CV, $\mathrm{R}^{2}$ values and APrec when compared with those of FFA model. This can be also observed from predicted vs actual value graph given in Figure1a. There was no outlier at Cook's distances for OSI values showing a good model fitting. All parameters were found to be effective on OSI values according to the p-values given in Table 3. In addition, the interaction between temperature and stripping steam (Figure 2c) and, temperature and pressure were found to be significant. Response surfaces of OSI values represented that at low stripping steam rates $(0.75 \mathrm{~g} / \mathrm{min})$, an increase in deodorization temperature reduced the OSI values, while at high stripping rates $(1.25 \mathrm{~g} / \mathrm{min})$ effect of deodorization temperature become directly proportional with the OSI values. At low stripping steam rates, increasing the deodorization temperature reduced the OSI drastically because of higher loss in tocopherols and carotenes at higher deodorization temperatures as tocopherols were volatile and both types of molecules were vulnerable to heat damage (Zulkurnain et al., 2013). Although the increase in OSI seems to be minor 
from Figure 2d as the deodorization pressure or time increased, this effect has found to be statistically important as well.

Coefficient for coded factors of FFA and OSI models were given in Table 3. The coefficient estimate represents the expected change in response per unit change in factor value when all remaining factors are held constant. Therefore, the model equation was represented on coded factors where lowest level coded as -1 and highest level was coded as +1 and the all levels in between are being calculated with respect to this scale. The coded values of each parameters actual level can be calculated using following equation (Silbir et al., 2014).

Eq 4 Coded Value $=\frac{\text { Actual level }-(\text { high level }+ \text { low level }) / 2}{(\text { high level-lowlevel }) / 2}$

Coefficients of temperature were negative representing an inversely proportional relationship while coefficients of pressure were positive which indicates a directly proportional relationship for both FFA and OSI models.

\section{Modeling the effect of deodorization parameters on deodorized canola oil fatty acid composition}

The fatty acid composition of bleached and deodorized canola oil samples was represented in Table 4. In addition to fatty acid composition total unsaturated fatty acid (UFA), polyunsaturated fatty acid (PUFA), monounsaturated fatty acid (MUFA) and saturated fatty acid content (SAFA) were calculated. The four major fatty acids of canola oil were cis-oleic acid (C18:1 cis) at 56.89\%, cis-linoleic acid (C18:2 cis) at 25.2\%, cis-linolenic acid (cis-C18:3) at 7.1\% and palmitic acid (C16:0) at 5.7\%. In general, PUFA and MUFA dominated much of the fatty acid profile which makes canola oil susceptible to isomerization reactions. Therefore, canola oil which had very low amount of trans fatty acids prior to deodorization experiments while a considerable isomerization occurred during almost all deodorization experiments. A decrease in C18:2cis and cis-C18:3 has been observed while trans isomers of those has increased at all deodorization experiment. This decrease in PUFA, also caused an increase in C16:0 and C18:1 percentage in total composition.

The models were developed using quadratic terms and reduced with backward substitution method. Only cisC18:3, tr-C18:3 and PUFA models showed significance while lack of fitness was insignificant as seen in Table 5. Temperature of deodorization was found to be effective on cis-C18:3, tr-C18:3 and PUFA percentages while the temperature increased cis-C18:3 levels were decreased and tr-C18:3 levels were increased. The amount of tr-C18:3 was directly a representation of trans isomerization in deodorized canola oil samples. Deodorization time was also effective on tr-C18:3 as well as the temperature. tr-C18:3 formation has increased as the deodorization temperature and time increased. The effect of temperature on tr-C18:3 formation has been reported with many researchers. In a previous study, the isomerization rates was discussed using degree of isomerization of each PUFA and indicated that as the deodorization temperature increased from $204^{\circ} \mathrm{C}$ to $230^{\circ} \mathrm{C}$, the degree of isomerization increased from about $40 \%$ to $65 \%$ for C18:3 during deodorization of canola oil using a pilot scale deodorizer (Kemény et al., 2001). The content of trans isomers in the deodorized oils was reported to depend on the fatty acid composition and on the deodorization temperature more than on the time or contaminants present in another study (Cmolik and Pokorny, 2000). Likewise, when the coefficients of deodorization temperature $(0.0583)$ and deodorization time $(0.0392)$ of the tr-C18:3 model compared, the effect of temperature was found to be superior than time in our study.

Deodorization pressure and stripping steam rate was not found statistically significant on the tr-C18:3 formation (Table 5). PUFA content has decreased most at high deodorization temperatures. However, the significant interaction effect between temperature and pressure can be observed in Figure $5 \mathrm{c}$ where at low pressures the temperature change did not affected PUFA content while the increase in deodorization temperature decreased the PUFA content as the deodorization pressure increased. 


\section{Optimization of canola oil deodorization parameters}

The mathematical models developed for FFA, OSI, tr-C18:3 and PUFA were used for multipurpose numerical optimization. For this optimization the aims were to obtain optimum deodorization temperature, pressure, stripping steam rate and time for obtaining a deodorized canola oil with low FFA, tr-C18:3 content and high OSI value and PUFA content. According to the numerical RSM optimization results given in Table 6 , optimum temperature, pressure, stripping steam, and time levels were calculated as $228.8^{\circ} \mathrm{C}, 1.4 \mathrm{mBar}$, $1.25 \mathrm{gr} / \mathrm{min}$ and 80 minutes, respectively. At this optimum point, the optimization model has predicted the FFA level to be $0.044 \%$, OSI as $10.65 \mathrm{~h}$, tr-C18:3 content as $0.21 \%$ and PUFA content as $30.50 \%$. Although optimization model has developed in accordance with three different targets, the desirable factor was 0.727 which can be considered relatively high showing numerical optimization well met with the optimization aims (Lazic, 2004). FFA, OSI tr-C18:3 and PUFA results of a validation experiment using this optimum condition has validated the predicted values of optimization model. The relative differences of FAA, OSI, tr-C18:3 and PUFA between predicted values and validation results were 9.09, 7.05, 14.49 and 10.78, respectively. All relative errors were smaller than CV's of each model showing these errors are within the range of the model fit statistics.

\section{Kinetic analysis of cis-C18:3 degradation and tr-C18:3 formation}

Trans fatty acids are mono- or polyunsaturated fatty acids with one or more double bonds in the "trans" configuration. In crude vegetable oils, double bonds are nearly always in the "cis" configuration, means the hydrogen atoms sterically located on the same side of the double bond. Because of the low activation energy, trans fatty acids are formed relatively easily at elevated temperatures such as during deodorization or hydrogenation (Brien et al., 2000). The reaction rates (k) of cis-C18:3 degradation and tr-C18:3 formation were calculated as slopes of each linear regression line from the plots showing the change in amount with respect to deodorization times for each deodorization temperature, as given Table 7. The linear relationships confirmed that the isomerization of linolenic acid is a first-order reaction. The $\mathrm{k}$ values of cis-C18:3 deterioration were $0.0032,0.0049$ and 0.0172 while the $\mathrm{k}$ values of tr- $\mathrm{C} 18: 3$ formation $0.0014,0.0024$ and 0.0034 at $220^{\circ} \mathrm{C}, 225^{\circ} \mathrm{C}$ and $230^{\circ} \mathrm{C}$ respectively. This difference in reaction rates means that during deodorization, the deterioration rates of cis-C18:3 were higher than those of the formation of C18:2trans. Therefore, not only isomerization is the cause of decrease in cis-C18:3 content but also there are other deterioration mechanisms occurred during deodorization. The reaction rates of cis-C18:3 deterioration were similar than those published by Hénon et al. (Hénon et al., 1999).

Arrhenius' equation was used to calculate the activation energies of tr-C18:3 formation and total deterioration in cis-C18:3. The linear plot of $\ln (k)$ values with respect to reciprocal of T was used to calculate $A$ and $E_{a}$ while $R$ was equal to $8.314 \times 10^{11} \mathrm{~J} \cdot \mathrm{K}^{-1} \cdot \mathrm{mol}^{-1}$. Activation energies were calculated as $346 \mathrm{~kJ} / \mathrm{mol}$ and $183 \mathrm{~kJ} / \mathrm{mol}$ for cis-C18:3 deterioration and C18:3trans formation, respectively. These findings are in accordance with the reported isomerization activation energy as $125 \mathrm{~kJ} / \mathrm{mol}$ for trans- fatty acid formation in vegetable oils. Moreover, authors indicated that than activation energy is low and easy to achieve at deodorization temperatures (Brien et al., 2000). Arrhenius' equations developed in our study were given in Eq 5 and Eq 6 .

Eq $5 . k_{c i s-C 18: 3}=1.3 \times 10^{34} \times e^{-\frac{346 \times 10^{3}}{8.314}}$

Eq $6 . k_{t r-C 18: 3}=3.5 \times 10^{16} \times e^{-\frac{183 \times 10^{3}}{8.314}}$

The change in $k$ of cis-C18:3 and tr-C18:3 according to relevant Arrhenius' equation within the experimental temperature range in our study was represented in Figure 6 . The exponential increase in degradation rate of the cis-C18:3 was clearly observed in deodorization temperature range of our study while the tr-C18:3 formation rates was remained lower than that of cis-C18:3. In a previous study, the isomerization rates were calculated using only cis-C18:3 contents of oil, however according to our findings, isomerization was not the only pathway for cis-C18:3 degradation according to difference in reaction rates (Hénon et al., 1999). Previous studies showed that deodorization in mild temperatures such as $80-130^{\circ} \mathrm{C}$ was not effective on fatty 
acid composition of oil (Aparicio-Ruiz et al., 2017). However when the temperature exceeds $180^{\circ} \mathrm{C}$, not only geometrical isomerization but also polarization and cyclization of unsaturated fatty acids is also expected (Fournier et al., 2007). Especially when the deodorization temperature exceeds $220^{\circ} \mathrm{C}$ isomerization reactions accelerate and it is suggested that the deodorization temperature should be kept lower than $180^{\circ} \mathrm{C}$ for oils rich in polyunsaturated fatty acids and activation energy will not be enough for isomerization when the deodorization temperature is lower than $180^{\circ} \mathrm{C}$ (Fournier et al., 2006).

\section{Conclusion}

The effects of refining, especially deodorization, on canola oil quality characteristics and fatty acid composition was discussed in this study. It is a known fact that elevated temperatures of deodorization have dramatical effects on minor components of vegetable oils. Among them, isomerization of the PUFA and "badcheese" odor which was reported for vegetable oils rich in high unsaturated fatty acids was mainly linked with the degradation of C18:3 into light molecular substances during deodorization. Therefore, the effect of four deodorization parameters on FFA content, PV, OSI, TPC, redness and fatty acid composition has been investigated and the factor-response relations explained through mathematical models. Temperature was significantly effective in inversely proportional for all modeled responses except tr-C18:3 content of deodorized canola oil. Pressure was found statistically effective on all responses except tr-C18:3, however the effect on OSI was superior when compared with others. The effect of stripping steam rate was directly proportional to OSI and cis-C18:3 content of deodorized canola oil and inversely proportional to FFA content. Stripping steam rate did not affect tr-C18:3 or PUFA content significantly. As deodorization time increased OSI and tr-C18:3 content of deodorized oils was also increased and cis-C18:3 decreased, significantly.

RSM optimization carried out with responses having only good model fit. The targets were lowest free fatty acid and trans-linolenic acid (tr-C18:3) contents and highest OSI value and polyunsaturated fatty acid content at deodorized canola oil. Optimum temperature, pressure, stripping steam, and time were $228.8^{\circ} \mathrm{C}, 1.4 \mathrm{mBar}, 1.25 \mathrm{gr} / \mathrm{min}$ and 80 minutes, and the predicted FFA content, OSI, tr-C18:3 content, and PUFA content were $0.044 \%, 10.65 \mathrm{~h}, 0.21 \%$ and $30.50 \%$, and the relative differences between predicted values and validation results were $9.09 \%, 7.05 \%, 14.49 \%$ and $10.78 \%$, respectively. Cis-C18:3 degradation rate was calculated as higher than tr-C18:3 formation rate at all deodorization temperatures. This degradation may cause formation of odoriferous light molecules that tend to be perceived as bad-cheese odor when the refined oil reheated. The determined reaction rate difference between degradation of cis-C18:3 and transC18:3 formation in our results should be further investigated by involving different vegetable oils at different unsaturation levels. Activation energy for fatty acid isomerization (tr-C18:3 formation) was $183 \mathrm{~kJ} / \mathrm{mol}$ which is a quite low and easy to achieve at commercial deodorization temperatures especially above $180^{\circ} \mathrm{C}$. From the above-mentioned findings, it can be followed that the key factor of the deodorization was temperature especially when the detrimental effects on deodorized canola oil quality considered. The refineries seeking a solution for a higher quality deodorized oil which rich in PUFA content in its "cis" form, should concentrate on developing deodorizers working with better heat transfer mechanisms to reduce deodorization temperature and time.

\section{References}

Aparicio-Ruiz, R., Romero, I., García-González, D. L., Oliver-Pozo, C., \& Aparicio, R. (2017). Softdeodorization of virgin olive oil: Study of the changes of quality and chemical composition. Food Chemistry ,220 , 42-50. https://doi.org/10.1016/j.foodchem.2016.09.176

Balasubramani, P., Palaniswamy, P. T., Visvanathan, R., Thirupathi, V., Subbarayan, A., \& Prakash Maran, J. (2015). Microencapsulation of garlic oleoresin using maltodextrin as wall material 
by spray drying technology. International Journal of Biological Macromolecules ,72 , 210-217. https://doi.org/10.1016/j.ijbiomac.2014.08.011

Brien, R. D. O., Farr, W. E., \& Wan, P. J. (2000). Introduction to Fats and Oils Technology (R. D. O. Brien, W. E. Farr, \& P. J. Wan (eds.)). AOCS Press.

Ceriani, R., Costa, A. M., \& Meirelles, A. J. A. (2008). Optimization of the physical refining of sunflower oil concerning the final contents of trans -fatty acids. Industrial and Engineering Chemistry Research , 47 (3), 681-692. https://doi.org/10.1021/ie070118p

Ceriani, R., \& Meirelles, A. J. A. (2004). Simulation of continuous deodorizers: Effects on product streams. JAOCS, Journal of the American Oil Chemists' Society , 81 (11), 1059-1069. https://doi.org/10.1007/s11746-004-1022-4

Ceriani, R., \& Meirelles, A. J. A. (2007). Formation of trans PUFA during deodorization of canola oil: A study through computational simulation. Chemical Engineering and Processing: Process Intensification , 46 (5), 375-385. https://doi.org/10.1016/j.cep.2006.05.023

Chew, S. C., Tan, C. P., Long, K., \& Nyam, K. L. (2016). Effect of chemical refining on the quality of kenaf (hibiscus cannabinus) seed oil. Industrial Crops and Products , 89 , 59-65. https://doi.org/10.1016/j.indcrop.2016.05.002

Cmolik, J., \& Pokorny, J. (2000). Physical refining of edible oils.European Journal of Lipid Science and Technology , 102 , 472-486.

De Greyt, W. F. J. (2012). Current and future technologies for the sustainable and cost-efficient production of high quality food oils.European Journal of Lipid Science and Technology , 114 , 1126-1139. https://doi.org/10.1002/ejlt.201200068

Deshmukh, R. K., \& Naik, J. B. (2015). Optimization of sustained release aceclofenac microspheres using response surface methodology.Materials Science $\&$ Engineering $C$, 48 , 197-204. https://doi.org/10.1016/j.msec.2014.12.008

Durmaz, G., \& Gökmen, V. (2019). Effect of refining on bioactive composition and oxidative stability of hazelnut oil. Food Research International , 116 (August 2018), 586-591. https://doi.org/10.1016/j.foodres.2018.08.077

Farhoosh, R., Einafshar, S., \& Sharayei, P. (2009). The effect of commercial refining steps on the rancidity measures of soybean and canola oils. Food Chemistry , 115 (3), 933-938. https://doi.org/10.1016/j.foodchem.2009.01.035

Fournier, V., Destaillats, F., Juanéda, P., Dionisi, F., Lambelet, P., Sébédio, J. L., \& Berdeaux, O. (2006). Thermal degradation of long-chain polyunsaturated fatty acids during deodorization of fish oil.European Journal of Lipid Science and Technology , 108 (1), 33-42. https://doi.org/10.1002/ejlt.200500290

Fournier, V., Destaillats, F., Lambelet, P., Dionisi, F., Sébédio, J.-L., \& Berdeaux, O. (2007). Degradation products formed from long-chain PUFA during deodorization of fish oil. Lipid Technology , 19 (1), 9-11. https://doi.org/10.1002/lite.200600003

Ghazani, S. M., García-Llatas, G., \& Marangoni, A. G. (2013). Minor constituents in canola oil processed by traditional and minimal refining methods. Journal of the American Oil Chemists' Society, 90 , 743-756. https://doi.org/10.1007/s11746-013-2215-2

Hénon, G., Kemény, Z., Recseg, K., Zwobada, F., \& Kovari, K. (1999). Deodorization of vegetable oils. Part I: Modelling the geometrical isomerization of polyunsaturated fatty acids. JAOCS, Journal of the American Oil Chemists' Society , 76 (1), 73-81. https://doi.org/10.1007/s11746-999-0050-2

Joaquín, J. S., Harwood, J. L., \& Enrique, M.-F. (2013). Lipid Metabolism in Olive: Biosynthesis of Triacylglycerols and Aroma Components. In Handbook of Olive Oil:Analysis and Properties (pp. 97-122). 
Kemény, Z., Recseg, K., Hénon, G., Kovári, K., \& Zwobada, F. (2001). Deodorization of vegetable oils: Prediction of trans polyunsaturated fatty acid content. JAOCS, Journal of the American Oil Chemists' Society , 78 (9), 973-979. https://doi.org/10.1007/s11746-001-0374-0

Kreps, F., Vrbiková, L., \& Schmidt, Š. (2014). Influence of industrial physical refining on tocopherol, chlorophyll and beta-carotene content in sunflower and rapeseed oil. European Journal of Lipid Science and Technology , 116 (11), 1572-1582. https://doi.org/10.1002/ejlt.201300460

Lazic, Z. R. (2004). Design of experiments in chemical engineering: a practical guide. Wiley-VCH.

Liu, R., Guo, X., Cheng, M., Zheng, L., Gong, M., Chang, M., Jin, Q., \& Wang, X. (2019). Effects of chemical refinement on the quality of coconut oil. Journal of Food Science and Technology ,56 (6), 31093116. https://doi.org/10.1007/s13197-019-03810-w

Marangoni, R. F., Dutra, T. V., \& Reitz Cardoso, F. A. (2019). Analysis of factors responsible for optimizing the clarification process of soybean oil: a care study using the desirability function.Separation Science and Technology (Philadelphia) , 0 (0), 1-9. https://doi.org/10.1080/01496395.2019.1609514

Oxidation stability of oils and fats - Rancimat method, Pub. L. No. 204/2 e, 4 (2016).

Myers, R., Montgomery, D., \& Anderson-Cook, C. (2011). Response surface methodology: process and product optimization using designed experiments (3rd edn.). Wiley.

Ortega-García, J., Gámez-Meza, N., Noriega-Rodriguez, J. A., Dennis-Quiñonez, O., García-Galindo, H. S., Angulo-Guerrero, J. O., \& Medina-Juárez, L. A. (2006). Refining of high oleic safflower oil: Effect on the sterols and tocopherols content. European Food Research and Technology , 223 , 775-779. https://doi.org/10.1007/s00217-006-0267-3

Özdikicierler, O., Yemişçioğlu, F., \& Saygın Gümüşkesen, A. (2016). Effects of process parameters on 3MCPD and glycidyl ester formation during steam distillation of olive oil and olive pomace oil.European Food Research and Technology ,242 , 805-813. https://doi.org/10.1007/s00217-015-2587-7

Pan, F., Wen, B., Wang, X., Ma, X., Zhao, J., Liu, C., Xu, Y., \& Dang, W. (2019). Effect of the chemical refining process on perilla seed oil composition and oxidative stability. Journal of Food Processing and Preservation, November 2018 , 1-10. https://doi.org/10.1111/jfpp.14094

Ruiz-Méndez, M. V., Márquez-Ruiz, G., \& Dobarganes, M. C. (1997). Relationships between quality of crude and refined edible oils based on quantitation of minor glyceridic compounds. Food Chemistry ,60 (4), 549-554. https://doi.org/10.1016/S0308-8146(97)00029-0

Sghaier, L., Vial, J., Sassiat, P., Thiebaut, D., Watiez, M., Breton, S., Rutledge, D. N., \& Cordella, C. B. Y. (2016). Analysis of target volatile compounds related to fishy off-flavor in heated rapeseed oil: A comparative study of different headspace techniques. European Journal of Lipid Science and Technology , 118 (6), 906-918. https://doi.org/10.1002/ejlt.201500088

Shahidi, F. (2005). Bailey's Industrial Oil and Fat Products (F. Shahidi (ed.); 6. Edition). John Wiley \& Sons, Inc.

Silbir, S., Dagbagli, S., Yegin, S., Baysal, T., \& Goksungur, Y. (2014). Levan production by Zymomonas mobilis in batch and continuous fermentation systems. Carbohydrate Polymers , 99 , 454-461. https://doi.org/10.1016/j.carbpol.2013.08.031

Suliman, T. E., Meng, Z., Li, J. W., Jiang, J., \& Liu, Y. (2013). Optimisation of sunflower oil deodorising: Balance between oil stability and other quality attributes. International Journal of Food Science and Technology , 48 (9), 1822-1827. https://doi.org/10.1111/ijfs.12156

Xie, D., Zhou, H., \& Jiang, X. (2019). Effect of chemical refining on the levels of bioactive components and hazardous substances in soybean oil. Journal of Food Measurement and Characterization ,13 (2), 1423-1430. https://doi.org/10.1007/s11694-019-00058-y 
Yoon, S. H. (2016). Optimization of the refining process and oxidative stability of chufa (Cyperus esculentus L.) oil for edible purposes.Food Science and Biotechnology , 25 (1), 85-90. https://doi.org/10.1007/s10068016-0012-z

Zulkurnain, M., Lai, O. M., Tan, S. C., Abdul Latip, R., \& Tan, C. P. (2013). Optimization of palm oil physical refining process for reduction of 3-monochloropropane-1,2-diol (3-MCPD) ester formation. Journal of Agricultural and Food Chemistry , 61 (13), 3341-3349. https://doi.org/10.1021/jf4009185

\section{Tables}

Table 1. Upper and lower limits of steam distillation parameters for Central Composite design.

\begin{tabular}{lllllll}
\hline Factor & Name & Unit & -alpha & Minimum (Code: -1$)$ & Center (Code: 0$)$ & Maximum (Code: $+\mathbf{1})$ \\
\hline $\mathrm{A}$ & Temperature & ${ }^{\circ} \mathrm{C}$ & 215 & 220 & 225 & 230 \\
$\mathrm{~B}$ & Pressure & $\mathrm{mBar}$ & 0.6 & 1.4 & 2.2 & 3 \\
$\mathrm{C}$ & Stripping Steam & $\mathrm{g} / \mathrm{min}$ & 0.5 & 0.75 & 1 & 1.25 \\
$\mathrm{D}$ & Time & $\mathrm{min}$ & 60 & 80 & 100 & 120 \\
\hline
\end{tabular}

Table 2. Quality characteristics of deodorized canola oil samples obtained via central composite experimental design

\begin{tabular}{lllllll}
\hline & Factors & Factors & Factors & Factors & Responses & Responses \\
\hline Run & A:Temperature & B:Pressure (mBar) & C:Stripping Steam (g/min) & D:Time & FFA (\%) & OSI (h) \\
Init & Init & Init & Init & Init & 0.071 & 7.5 \\
1 & 230 & 1.4 & 1.25 & 80 & 0.04 & 10.68 \\
2 & 220 & 3 & 0.75 & 80 & 0.07 & 10.9 \\
3 & 230 & 3 & 1.25 & 120 & 0.05 & 11.14 \\
4 & 225 & 2.2 & 1 & 140 & 0.06 & 10.76 \\
5 & 220 & 1.4 & 0.75 & 120 & 0.07 & 10.94 \\
6 & 230 & 3 & 1.25 & 80 & 0.049 & 11.24 \\
7 & 220 & 3 & 1.25 & 120 & 0.06 & 10.5 \\
8 & 225 & 2.2 & 1 & 100 & 0.06 & 10.63 \\
9 & 220 & 3 & 1.25 & 80 & 0.06 & 10.53 \\
10 & 230 & 1.4 & 1.25 & 120 & 0.04 & 11.06 \\
11 & 220 & 1.4 & 0.75 & 80 & 0.06 & 10.96 \\
12 & 220 & 1.4 & 1.25 & 120 & 0.05 & 10.56 \\
13 & 225 & 2.2 & 1 & 100 & 0.07 & 10.54 \\
14 & 235 & 2.2 & 1 & 100 & 0.06 & 10.4 \\
15 & 215 & 2.2 & 1 & 100 & 0.067 & 10.78 \\
16 & 225 & 2.2 & 1 & 100 & 0.06 & 10.61 \\
17 & 230 & 3 & 0.75 & 80 & 0.06 & 10 \\
18 & 220 & 1.4 & 1.25 & 80 & 0.05 & 10.48 \\
19 & 230 & 1.4 & 0.75 & 120 & 0.06 & 9.7 \\
20 & 225 & 2.2 & 1 & 60 & 0.064 & 10.39 \\
21 & 225 & 3.8 & 1 & 100 & 0.054 & 10.7 \\
22 & 230 & 1.4 & 0.75 & 80 & 0.058 & 9.5 \\
23 & 230 & 3 & 0.75 & 120 & 0.062 & 10.35 \\
24 & 225 & 0.6 & 1 & 100 & 0.044 & 10.16
\end{tabular}




\begin{tabular}{lllllll}
\hline & Factors & Factors & Factors & Factors & Responses & Response \\
\hline 25 & 225 & 2.2 & 1 & 100 & 0.067 & 10.3 \\
26 & 225 & 2.2 & 0.5 & 100 & 0.077 & 10.44 \\
27 & 220 & 3 & 0.75 & 120 & 0.07 & 11.3 \\
28 & 225 & 2.2 & 1 & 100 & 0.067 & 10.67 \\
29 & 225 & 2.2 & 1 & 100 & 0.061 & 10.7 \\
30 & 225 & 2.2 & 1.5 & 100 & 0.05 & 10.8 \\
\hline
\end{tabular}

Table 3. ANOVA and fit statistics for reduced quadratic model of FFA and OSI

\begin{tabular}{|c|c|c|c|c|c|c|c|c|c|}
\hline $\begin{array}{l}\text { Model } \\
\text { statis- } \\
\text { tics of } \\
\text { cis- } \\
\text { C18:3 } \\
\text { fatty } \\
\text { acid }\end{array}$ & $\begin{array}{l}\text { Model } \\
\text { statis- } \\
\text { tics of } \\
\text { cis- } \\
\text { C18:3 } \\
\text { fatty } \\
\text { acid }\end{array}$ & $\begin{array}{l}\text { Model } \\
\text { statis- } \\
\text { tics of } \\
\text { cis- } \\
\text { C18:3 } \\
\text { fatty } \\
\text { acid }\end{array}$ & $\begin{array}{l}\text { Model } \\
\text { statis- } \\
\text { tics of } \\
\text { cis- } \\
\text { C18:3 } \\
\text { fatty } \\
\text { acid }\end{array}$ & $\begin{array}{l}\text { Model } \\
\text { statis- } \\
\text { tics of } \\
\text { cis- } \\
\text { C18:3 } \\
\text { fatty } \\
\text { acid }\end{array}$ & $\begin{array}{l}\text { Model } \\
\text { statis- } \\
\text { tics of } \\
\text { cis- } \\
\text { C18:3 } \\
\text { fatty } \\
\text { acid }\end{array}$ & $\begin{array}{l}\text { Model } \\
\text { statis- } \\
\text { tics of } \\
\text { cis- } \\
\text { C18:3 } \\
\text { fatty } \\
\text { acid }\end{array}$ & $\begin{array}{l}\text { Model } \\
\text { statis- } \\
\text { tics of } \\
\text { cis- } \\
\text { C18:3 } \\
\text { fatty } \\
\text { acid }\end{array}$ & $\begin{array}{l}\text { Model } \\
\text { statis- } \\
\text { tics of } \\
\text { cis- } \\
\text { C18:3 } \\
\text { fatty } \\
\text { acid }\end{array}$ & $\begin{array}{l}\text { Model } \\
\text { statis- } \\
\text { tics of } \\
\text { cis- } \\
\text { C18:3 } \\
\text { fatty } \\
\text { acid }\end{array}$ \\
\hline Source & $\begin{array}{l}\text { Sum } \\
\text { of } \\
\text { Squares }\end{array}$ & df & $\begin{array}{l}\text { Mean } \\
\text { Square }\end{array}$ & $\begin{array}{l}\text { F- } \\
\text { value }\end{array}$ & $\begin{array}{l}\mathrm{p}- \\
\text { value }\end{array}$ & & \multicolumn{2}{|c|}{$\begin{array}{l}\text { Coefficient } \\
\text { Esti- } \\
\text { mate }\end{array}$} & $\begin{array}{l}\text { Fit } \\
\text { Statis- } \\
\text { tics }\end{array}$ \\
\hline Model & 3.24 & 8 & 0.4051 & 33.75 & $\begin{array}{l}< \\
0.0001\end{array}$ & & \multicolumn{2}{|c|}{5.80} & $\begin{array}{l}\text { Std. } \\
\text { Dev. }\end{array}$ \\
\hline $\begin{array}{l}\text { A- } \\
\text { Temperature }\end{array}$ & $e^{1.15}$ & 1 & 1.15 & 96.04 & $<0.0001$ & & \multicolumn{2}{|l|}{-0.2192} & Mean \\
\hline $\begin{array}{l}\text { B- } \\
\text { Pressure }\end{array}$ & 0.0963 & 1 & 0.0963 & 8.02 & 0.0100 & & \multicolumn{2}{|l|}{0.0633} & C.V. \% \\
\hline $\begin{array}{l}\text { C- } \\
\text { Stripping } \\
\text { Steam }\end{array}$ & 0.4593 & 1 & 0.4593 & 38.26 & $<0.0001$ & & \multicolumn{2}{|l|}{0.1383} & $\mathbf{R}^{2}$ \\
\hline D-Time & 0.5340 & 1 & 0.5340 & 44.49 & $<0.0001$ & & \multicolumn{2}{|l|}{-0.1492} & $\begin{array}{l}\text { Adjusted } \\
\mathbf{R}^{\mathbf{2}}\end{array}$ \\
\hline $\mathrm{AC}$ & 0.2704 & 1 & 0.2704 & 22.53 & 0.0001 & & \multicolumn{2}{|l|}{0.1300} & $\begin{array}{l}\text { Predicted } \\
\mathbf{R}^{2}\end{array}$ \\
\hline $\mathrm{AD}$ & 0.1980 & 1 & 0.1980 & 16.50 & 0.0006 & & \multirow{3}{*}{\multicolumn{2}{|c|}{$\begin{array}{l}-0.1112 \\
0.1338 \\
-0.0919\end{array}$}} & APrec \\
\hline CD & 0.2862 & 1 & 0.2862 & 23.85 & $<0.0001$ & & & & \\
\hline $\mathrm{C}^{2}$ & 0.2435 & 1 & 0.2435 & 20.28 & 0.0002 & & & & \\
\hline Residual & 0.2521 & 21 & 0.0120 & & & & & & \\
\hline $\begin{array}{l}\text { Lack of } \\
\text { Fit }\end{array}$ & 0.2184 & 16 & 0.0136 & 2.03 & 0.2236 & & & & \\
\hline $\begin{array}{l}\text { Pure } \\
\text { Error }\end{array}$ & 0.0337 & 5 & 0.0067 & & & & & & \\
\hline $\begin{array}{l}\text { Corrected } \\
\text { Total }\end{array}$ & 3.49 & 29 & & & & & & & \\
\hline $\begin{array}{l}\text { Model } \\
\text { statis- } \\
\text { tics of } \\
\text { tr- } \\
\text { C18:3 } \\
\text { fatty } \\
\text { acid }\end{array}$ & $\begin{array}{l}\text { Model } \\
\text { statis- } \\
\text { tics of } \\
\text { tr- } \\
\text { C18:3 } \\
\text { fatty } \\
\text { acid }\end{array}$ & $\begin{array}{l}\text { Model } \\
\text { statis- } \\
\text { tics of } \\
\text { tr- } \\
\text { C18:3 } \\
\text { fatty } \\
\text { acid }\end{array}$ & $\begin{array}{l}\text { Model } \\
\text { statis- } \\
\text { tics of } \\
\text { tr- } \\
\text { C18:3 } \\
\text { fatty } \\
\text { acid }\end{array}$ & $\begin{array}{l}\text { Model } \\
\text { statis- } \\
\text { tics of } \\
\text { tr- } \\
\text { C18:3 } \\
\text { fatty } \\
\text { acid }\end{array}$ & $\begin{array}{l}\text { Model } \\
\text { statis- } \\
\text { tics of } \\
\text { tr- } \\
\text { C18:3 } \\
\text { fatty } \\
\text { acid }\end{array}$ & $\begin{array}{l}\text { Model } \\
\text { statis- } \\
\text { tics of } \\
\text { tr- } \\
\text { C18:3 } \\
\text { fatty } \\
\text { acid }\end{array}$ & $\begin{array}{l}\text { Model } \\
\text { statis- } \\
\text { tics of } \\
\text { tr- } \\
\text { C18:3 } \\
\text { fatty } \\
\text { acid }\end{array}$ & $\begin{array}{l}\text { Model } \\
\text { statis- } \\
\text { tics of } \\
\text { tr- } \\
\text { C18:3 } \\
\text { fatty } \\
\text { acid }\end{array}$ & $\begin{array}{l}\text { Model } \\
\text { statis- } \\
\text { tics of } \\
\text { tr- } \\
\text { C18:3 } \\
\text { fatty } \\
\text { acid }\end{array}$ \\
\hline
\end{tabular}




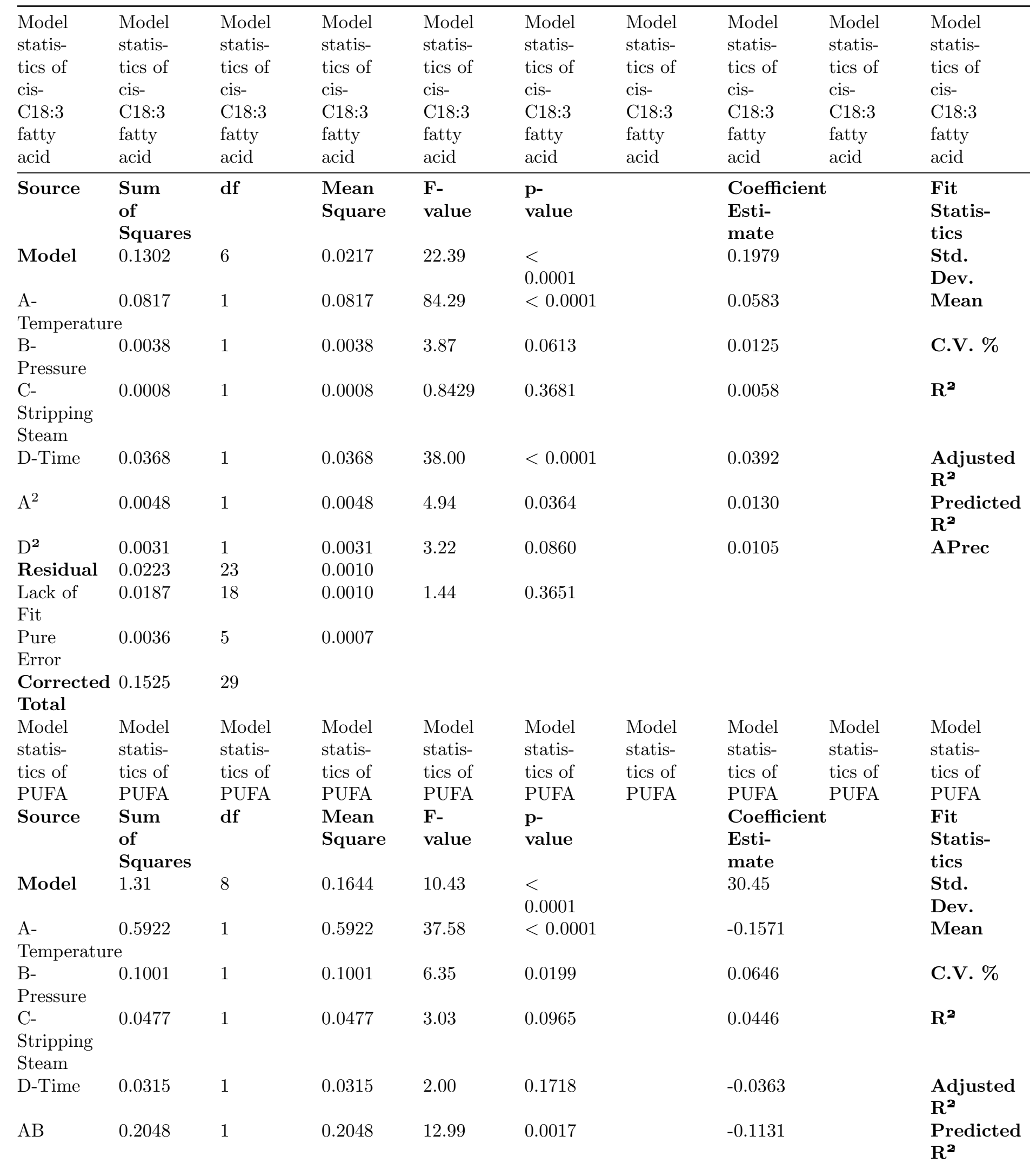




\begin{tabular}{|c|c|c|c|c|c|c|c|c|c|}
\hline $\begin{array}{l}\text { Model } \\
\text { statis- } \\
\text { tics of } \\
\text { cis- } \\
\text { C18:3 } \\
\text { fatty } \\
\text { acid }\end{array}$ & $\begin{array}{l}\text { Model } \\
\text { statis- } \\
\text { tics of } \\
\text { cis- } \\
\text { C18:3 } \\
\text { fatty } \\
\text { acid }\end{array}$ & $\begin{array}{l}\text { Model } \\
\text { statis- } \\
\text { tics of } \\
\text { cis- } \\
\text { C18:3 } \\
\text { fatty } \\
\text { acid }\end{array}$ & $\begin{array}{l}\text { Model } \\
\text { statis- } \\
\text { tics of } \\
\text { cis- } \\
\text { C18:3 } \\
\text { fatty } \\
\text { acid }\end{array}$ & $\begin{array}{l}\text { Model } \\
\text { statis- } \\
\text { tics of } \\
\text { cis- } \\
\text { C18:3 } \\
\text { fatty } \\
\text { acid }\end{array}$ & $\begin{array}{l}\text { Model } \\
\text { statis- } \\
\text { tics of } \\
\text { cis- } \\
\text { C18:3 } \\
\text { fatty } \\
\text { acid }\end{array}$ & $\begin{array}{l}\text { Model } \\
\text { statis- } \\
\text { tics of } \\
\text { cis- } \\
\text { C18:3 } \\
\text { fatty } \\
\text { acid }\end{array}$ & $\begin{array}{l}\text { Model } \\
\text { statis- } \\
\text { tics of } \\
\text { cis- } \\
\text { C18:3 } \\
\text { fatty } \\
\text { acid }\end{array}$ & $\begin{array}{l}\text { Model } \\
\text { statis- } \\
\text { tics of } \\
\text { cis- } \\
\text { C18:3 } \\
\text { fatty } \\
\text { acid }\end{array}$ & $\begin{array}{l}\text { Model } \\
\text { statis- } \\
\text { tics of } \\
\text { cis- } \\
\text { C18:3 } \\
\text { fatty } \\
\text { acid }\end{array}$ \\
\hline $\mathrm{AC}$ & 0.1208 & 1 & 0.1208 & 7.66 & 0.0115 & & 0.0869 & & APrec \\
\hline $\mathrm{AD}$ & 0.1106 & 1 & 0.1106 & 7.02 & 0.0150 & & -0.0831 & & \\
\hline $\mathrm{B}^{2}$ & 0.1073 & 1 & 0.1073 & 6.81 & 0.0164 & & -0.0610 & & \\
\hline Residual & 0.3309 & 21 & 0.0158 & & & & & & \\
\hline $\begin{array}{l}\text { Lack of } \\
\text { Fit }\end{array}$ & 0.2164 & 16 & 0.0135 & 0.5903 & 0.8069 & & & & \\
\hline $\begin{array}{l}\text { Pure } \\
\text { Error }\end{array}$ & 0.1145 & 5 & 0.0229 & & & & & & \\
\hline $\begin{array}{l}\text { Corrected } \\
\text { Total }\end{array}$ & 1.65 & 29 & & & & & & & \\
\hline
\end{tabular}

Table 4. Fatty acid composition and UFA, PUFA, MUFA, SAFA percentages of deodorized canola oil samples obtained via central composite experimental design

\begin{tabular}{|c|c|c|c|c|c|c|c|c|c|c|c|c|}
\hline$\overline{\text { Run }}$ & $\mathrm{C} 12: 0$ & C14:0 & C16:0 & $\mathrm{C} 16: 1$ & C18:0 & tr-C18:1 & cis-C18:1 & tr-C18:2 & cis-C18:2 & tr-C18:3 & cis-C18:3 & C20: \\
\hline Init. & 0.06 & 0.09 & 5.7 & 0.23 & 2.11 & 0.03 & 56.89 & 0 & 25.2 & 0 & 7.1 & 0.51 \\
\hline 1 & 0.05 & 0.08 & 6.54 & 0.17 & 1.95 & 0.39 & 57.85 & 0.11 & 24.31 & 0.22 & 5.9 & 0.46 \\
\hline 2 & 0.04 & 0.1 & 6.58 & 0.22 & 1.95 & 0.37 & 57.7 & 0.07 & 24.35 & 0.13 & 6.15 & 0.46 \\
\hline 3 & 0.04 & 0.1 & 6.62 & 0.21 & 1.99 & 0.89 & 57.68 & 0.21 & 24.13 & 0.34 & 5.61 & 0.51 \\
\hline 4 & 0.04 & 0.11 & 6.59 & 0.2 & 1.95 & 0.33 & 57.72 & 0.16 & 24.33 & 0.34 & 5.61 & 0.49 \\
\hline 5 & 0.05 & 0.11 & 6.81 & 0.21 & 2.04 & 0.42 & 57.62 & 0.14 & 24.26 & 0.22 & 5.72 & 0.49 \\
\hline 6 & 0.05 & 0.11 & 6.56 & 0.22 & 1.95 & 0.35 & 57.75 & 0.1 & 24.35 & 0.23 & 5.84 & 0.49 \\
\hline 7 & 0.05 & 0.11 & 6.48 & 0.23 & 1.92 & 0.33 & 57.73 & 0.11 & 24.41 & 0.18 & 6.04 & 0.48 \\
\hline 8 & 0.05 & 0.11 & 6.55 & 0.22 & 1.95 & 0.38 & 57.67 & 0.12 & 24.36 & 0.24 & 5.86 & 0.49 \\
\hline 9 & 0.05 & 0.11 & 6.6 & 0.2 & 1.96 & 0.29 & 57.74 & 0.09 & 24.29 & 0.14 & 6.12 & 0.49 \\
\hline 10 & 0.04 & 0.11 & 6.61 & 0.19 & 1.95 & 0.14 & 57.95 & 0.13 & 24.16 & 0.32 & 5.64 & 0.49 \\
\hline 11 & 0.05 & 0.11 & 6.52 & 0.18 & 1.95 & 0.34 & 57.68 & 0.08 & 23.99 & 0.15 & 6.13 & 0.49 \\
\hline 12 & 0.06 & 0.12 & 6.85 & 0.22 & 2 & 0.32 & 57.56 & 0 & 24.31 & 0.17 & 5.98 & 0.5 \\
\hline 13 & 0.05 & 0.11 & 6.75 & 0.21 & 2.01 & 0.4 & 57.75 & 0 & 24.2 & 0.18 & 5.87 & 0.5 \\
\hline 14 & 0.07 & 0.13 & 6.91 & 0.22 & 2.03 & 0 & 57.99 & 0.21 & 23.96 & 0.39 & 5.46 & 0.46 \\
\hline 15 & 0.1 & 0.13 & 6.69 & 0.18 & 2.01 & 0.37 & 57.4 & 0 & 24.45 & 0.12 & 6.16 & 0.49 \\
\hline 16 & 0.06 & 0.11 & 6.63 & 0.2 & 1.99 & 0.4 & 57.73 & 0.11 & 24.24 & 0.22 & 5.83 & 0.5 \\
\hline 17 & 0.06 & 0.11 & 6.82 & 0.23 & 2.01 & 0.42 & 57.64 & 0.13 & 24.08 & 0.23 & 5.71 & 0.5 \\
\hline 18 & 0.17 & 0.23 & 8.13 & 0.22 & 2.51 & 0.43 & 56.65 & 0.1 & 24.27 & 0.13 & 5.74 & 0.51 \\
\hline 19 & 0.14 & 0.2 & 9.68 & 0.2 & 2.51 & 0.38 & 54.62 & 0.17 & 25.06 & 0.24 & 4.65 & 0.46 \\
\hline 20 & 0.07 & 0.11 & 6.83 & 0.22 & 2.03 & 0.37 & 57.46 & 0.11 & 24.27 & 0.15 & 6 & 0.5 \\
\hline 21 & 0.07 & 0.13 & 6.81 & 0.23 & 2.03 & 0.42 & 57.51 & 0.13 & 24.2 & 0.22 & 5.81 & 0.46 \\
\hline 22 & 0.17 & 0.15 & 6.84 & 0.21 & 2.09 & 0.4 & 57.42 & 0.15 & 24.17 & 0.24 & 5.65 & 0.24 \\
\hline 23 & 0.05 & 0.11 & 6.82 & 0.22 & 2.05 & 0.43 & 57.77 & 0.32 & 24.16 & 0.36 & 4.91 & 0.49 \\
\hline 24 & 0.08 & 0.12 & 6.63 & 0.29 & 1.98 & 0.36 & 59.78 & 0.17 & 24.3 & 0.13 & 5.48 & 0 \\
\hline 25 & 0.05 & 0.11 & 6.94 & 0.22 & 2.05 & 0.42 & 57.55 & 0.14 & 24.23 & 0.19 & 5.85 & 0.48 \\
\hline 26 & 0.15 & 0.2 & 10.52 & 0.2 & 2.66 & 0.3 & 53.36 & 0 & 25.44 & 0.15 & 5.08 & 0.46 \\
\hline 27 & 0 & 0 & 6.85 & 0.19 & 2.02 & 0 & 57.8 & 0.12 & 24.5 & 0.2 & 5.89 & 0 \\
\hline
\end{tabular}




\begin{tabular}{lllllllllllll}
\hline Run & C12:0 & C14:0 & C16:0 & C16:1 & C18:0 & tr-C18:1 & cis-C18:1 & tr-C18:2 & cis-C18:2 & tr-C18:3 & cis-C18:3 & C20:0 \\
\hline 28 & 0 & 0 & 7.32 & 0.19 & 2.02 & 0 & 59.98 & 0.15 & 24.24 & 0.24 & 5.65 & 0 \\
29 & 0 & 0 & 6.77 & 0.19 & 2.02 & 0 & 59.8 & 0 & 24.62 & 0.19 & 5.81 & 0 \\
30 & 0 & 0 & 6.78 & 0.18 & 1.99 & 0 & 59.9 & 0.13 & 24.45 & 0.24 & 5.71 & 0 \\
\hline
\end{tabular}

Table 5. ANOVA and fit statistics for reduced quadratic model of cis-C18:3, tr-C18:3 and PUFA

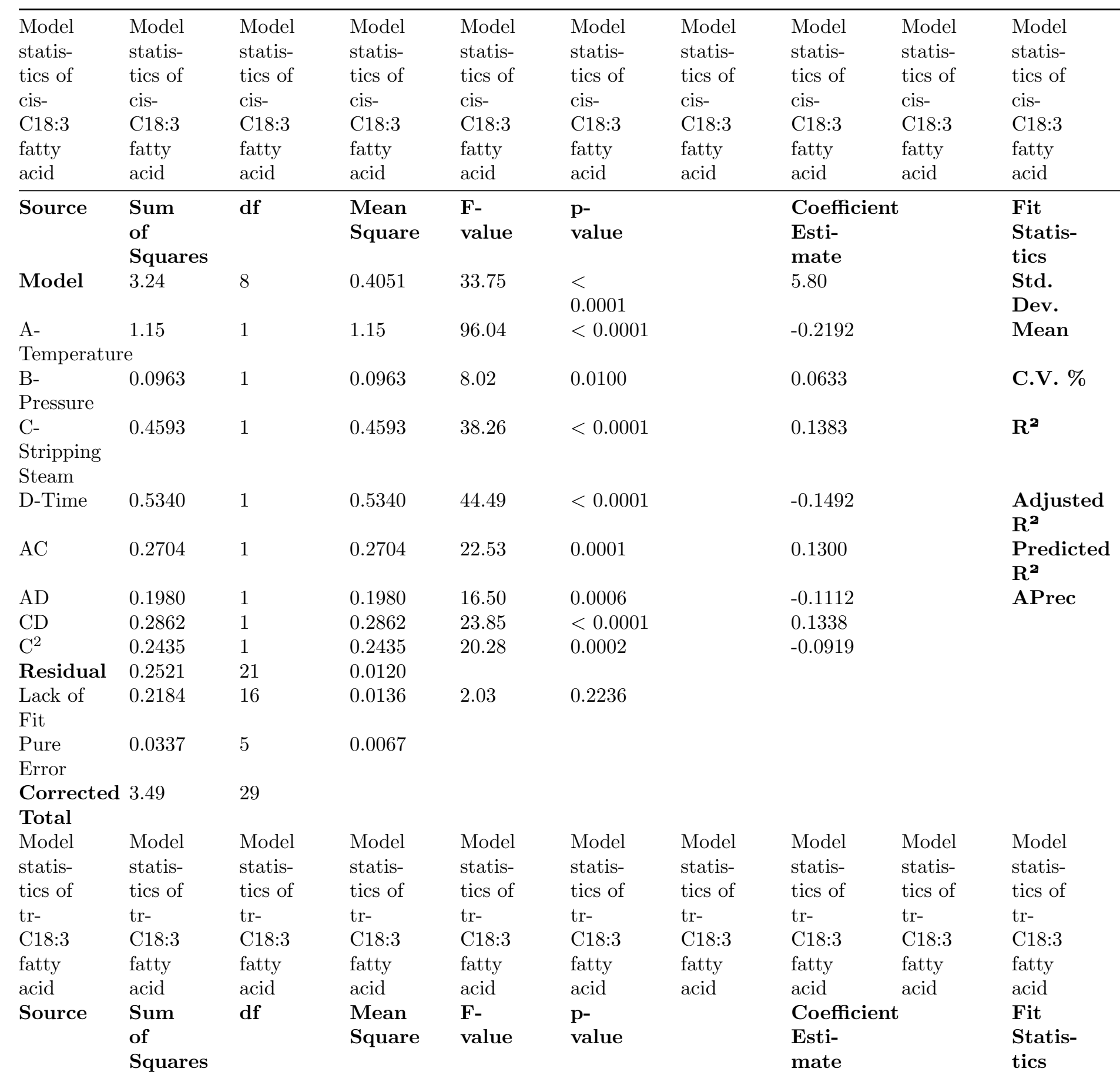




\begin{tabular}{|c|c|c|c|c|c|c|c|c|c|}
\hline $\begin{array}{l}\text { Model } \\
\text { statis- } \\
\text { tics of } \\
\text { cis- } \\
\text { C18:3 } \\
\text { fatty } \\
\text { acid }\end{array}$ & $\begin{array}{l}\text { Model } \\
\text { statis- } \\
\text { tics of } \\
\text { cis- } \\
\text { C18:3 } \\
\text { fatty } \\
\text { acid }\end{array}$ & $\begin{array}{l}\text { Model } \\
\text { statis- } \\
\text { tics of } \\
\text { cis- } \\
\text { C18:3 } \\
\text { fatty } \\
\text { acid }\end{array}$ & $\begin{array}{l}\text { Model } \\
\text { statis- } \\
\text { tics of } \\
\text { cis- } \\
\text { C18:3 } \\
\text { fatty } \\
\text { acid }\end{array}$ & $\begin{array}{l}\text { Model } \\
\text { statis- } \\
\text { tics of } \\
\text { cis- } \\
\text { C18:3 } \\
\text { fatty } \\
\text { acid }\end{array}$ & $\begin{array}{l}\text { Model } \\
\text { statis- } \\
\text { tics of } \\
\text { cis- } \\
\text { C18:3 } \\
\text { fatty } \\
\text { acid }\end{array}$ & $\begin{array}{l}\text { Model } \\
\text { statis- } \\
\text { tics of } \\
\text { cis- } \\
\text { C18:3 } \\
\text { fatty } \\
\text { acid }\end{array}$ & $\begin{array}{l}\text { Model } \\
\text { statis- } \\
\text { tics of } \\
\text { cis- } \\
\text { C18:3 } \\
\text { fatty } \\
\text { acid }\end{array}$ & $\begin{array}{l}\text { Model } \\
\text { statis- } \\
\text { tics of } \\
\text { cis- } \\
\text { C18:3 } \\
\text { fatty } \\
\text { acid }\end{array}$ & $\begin{array}{l}\text { Model } \\
\text { statis- } \\
\text { tics of } \\
\text { cis- } \\
\text { C18:3 } \\
\text { fatty } \\
\text { acid }\end{array}$ \\
\hline Model & 0.1302 & 6 & 0.0217 & 22.39 & $\begin{array}{l}< \\
0.0001\end{array}$ & & 0.1979 & & $\begin{array}{l}\text { Std. } \\
\text { Dev. }\end{array}$ \\
\hline $\begin{array}{l}\text { A- } \\
\text { Temperatur }\end{array}$ & $e^{0.0817}$ & 1 & 0.0817 & 84.29 & $<0.0001$ & & 0.0583 & & Mean \\
\hline $\begin{array}{l}\text { B- } \\
\text { Pressure }\end{array}$ & 0.0038 & 1 & 0.0038 & 3.87 & 0.0613 & & 0.0125 & & C.V. \% \\
\hline $\begin{array}{l}\text { C- } \\
\text { Stripping } \\
\text { Steam }\end{array}$ & 0.0008 & 1 & 0.0008 & 0.8429 & 0.3681 & & 0.0058 & & $\mathbf{R}^{2}$ \\
\hline D-Time & 0.0368 & 1 & 0.0368 & 38.00 & $<0.0001$ & & 0.0392 & & $\begin{array}{l}\text { Adjusted } \\
\mathbf{R}^{\mathbf{2}}\end{array}$ \\
\hline $\mathrm{A}^{2}$ & 0.0048 & 1 & 0.0048 & 4.94 & 0.0364 & & 0.0130 & & $\begin{array}{l}\text { Predicted } \\
\mathbf{R}^{\mathbf{2}}\end{array}$ \\
\hline $\mathrm{D}^{2}$ & 0.0031 & 1 & 0.0031 & 3.22 & 0.0860 & & 0.0105 & & APrec \\
\hline Residual & 0.0223 & 23 & 0.0010 & & & & & & \\
\hline $\begin{array}{l}\text { Lack of } \\
\text { Fit }\end{array}$ & 0.0187 & 18 & 0.0010 & 1.44 & 0.3651 & & & & \\
\hline $\begin{array}{l}\text { Pure } \\
\text { Error }\end{array}$ & 0.0036 & 5 & 0.0007 & & & & & & \\
\hline $\begin{array}{l}\text { Corrected } \\
\text { Total }\end{array}$ & 0.1525 & 29 & & & & & & & \\
\hline $\begin{array}{l}\text { Model } \\
\text { statis- } \\
\text { tics of } \\
\text { PUFA }\end{array}$ & $\begin{array}{l}\text { Model } \\
\text { statis- } \\
\text { tics of } \\
\text { PUFA }\end{array}$ & $\begin{array}{l}\text { Model } \\
\text { statis- } \\
\text { tics of } \\
\text { PUFA }\end{array}$ & $\begin{array}{l}\text { Model } \\
\text { statis- } \\
\text { tics of } \\
\text { PUFA }\end{array}$ & $\begin{array}{l}\text { Model } \\
\text { statis- } \\
\text { tics of } \\
\text { PUFA }\end{array}$ & $\begin{array}{l}\text { Model } \\
\text { statis- } \\
\text { tics of } \\
\text { PUFA }\end{array}$ & $\begin{array}{l}\text { Model } \\
\text { statis- } \\
\text { tics of } \\
\text { PUFA }\end{array}$ & $\begin{array}{l}\text { Model } \\
\text { statis- } \\
\text { tics of } \\
\text { PUFA }\end{array}$ & $\begin{array}{l}\text { Model } \\
\text { statis- } \\
\text { tics of } \\
\text { PUFA }\end{array}$ & $\begin{array}{l}\text { Model } \\
\text { statis- } \\
\text { tics of } \\
\text { PUFA }\end{array}$ \\
\hline Source & $\begin{array}{l}\text { Sum } \\
\text { of } \\
\text { Squares }\end{array}$ & df & $\begin{array}{l}\text { Mean } \\
\text { Square }\end{array}$ & $\begin{array}{l}\text { F- } \\
\text { value }\end{array}$ & $\begin{array}{l}\mathrm{p}- \\
\text { value }\end{array}$ & & $\begin{array}{l}\text { Coeffic } \\
\text { Esti- } \\
\text { mate }\end{array}$ & & $\begin{array}{l}\text { Fit } \\
\text { Statis- } \\
\text { tics }\end{array}$ \\
\hline Model & 1.31 & 8 & 0.1644 & 10.43 & $\begin{array}{l}< \\
0.0001\end{array}$ & & 30.45 & & $\begin{array}{l}\text { Std. } \\
\text { Dev. }\end{array}$ \\
\hline $\begin{array}{l}\text { A- } \\
\text { Temperatur }\end{array}$ & $e^{0.5922}$ & 1 & 0.5922 & 37.58 & $<0.0001$ & & -0.1571 & & Mean \\
\hline $\begin{array}{l}\text { B- } \\
\text { Pressure }\end{array}$ & 0.1001 & 1 & 0.1001 & 6.35 & 0.0199 & & 0.0646 & & C.V. \% \\
\hline $\begin{array}{l}\text { C- } \\
\text { Stripping } \\
\text { Steam }\end{array}$ & 0.0477 & 1 & 0.0477 & 3.03 & 0.0965 & & 0.0446 & & $\mathbf{R}^{2}$ \\
\hline D-Time & 0.0315 & 1 & 0.0315 & 2.00 & 0.1718 & & -0.0363 & & $\begin{array}{l}\text { Adjusted } \\
\mathbf{R}^{\mathbf{2}}\end{array}$ \\
\hline $\mathrm{AB}$ & 0.2048 & 1 & 0.2048 & 12.99 & 0.0017 & & -0.1131 & & $\begin{array}{l}\text { Predicted } \\
\mathbf{R}^{\mathbf{2}}\end{array}$ \\
\hline $\mathrm{AC}$ & 0.1208 & 1 & 0.1208 & 7.66 & 0.0115 & & 0.0869 & & APrec \\
\hline AD & 0.1106 & 1 & 0.1106 & 7.02 & 0.0150 & & -0.0831 & & \\
\hline $\mathrm{B}^{2}$ & 0.1073 & 1 & 0.1073 & 6.81 & 0.0164 & & -0.0610 & & \\
\hline
\end{tabular}




\begin{tabular}{|c|c|c|c|c|c|c|c|c|c|}
\hline $\begin{array}{l}\text { Model } \\
\text { statis- } \\
\text { tics of } \\
\text { cis- } \\
\text { C18:3 } \\
\text { fatty } \\
\text { acid }\end{array}$ & $\begin{array}{l}\text { Model } \\
\text { statis- } \\
\text { tics of } \\
\text { cis- } \\
\text { C18:3 } \\
\text { fatty } \\
\text { acid }\end{array}$ & $\begin{array}{l}\text { Model } \\
\text { statis- } \\
\text { tics of } \\
\text { cis- } \\
\text { C18:3 } \\
\text { fatty } \\
\text { acid }\end{array}$ & $\begin{array}{l}\text { Model } \\
\text { statis- } \\
\text { tics of } \\
\text { cis- } \\
\text { C18:3 } \\
\text { fatty } \\
\text { acid }\end{array}$ & $\begin{array}{l}\text { Model } \\
\text { statis- } \\
\text { tics of } \\
\text { cis- } \\
\text { C18:3 } \\
\text { fatty } \\
\text { acid }\end{array}$ & $\begin{array}{l}\text { Model } \\
\text { statis- } \\
\text { tics of } \\
\text { cis- } \\
\text { C18:3 } \\
\text { fatty } \\
\text { acid }\end{array}$ & $\begin{array}{l}\text { Model } \\
\text { statis- } \\
\text { tics of } \\
\text { cis- } \\
\text { C18:3 } \\
\text { fatty } \\
\text { acid }\end{array}$ & $\begin{array}{l}\text { Model } \\
\text { statis- } \\
\text { tics of } \\
\text { cis- } \\
\text { C18:3 } \\
\text { fatty } \\
\text { acid }\end{array}$ & $\begin{array}{l}\text { Model } \\
\text { statis- } \\
\text { tics of } \\
\text { cis- } \\
\text { C18:3 } \\
\text { fatty } \\
\text { acid }\end{array}$ & $\begin{array}{l}\text { Model } \\
\text { statis- } \\
\text { tics of } \\
\text { cis- } \\
\text { C18:3 } \\
\text { fatty } \\
\text { acid }\end{array}$ \\
\hline Residual & 0.3309 & 21 & 0.0158 & & & & & & \\
\hline $\begin{array}{l}\text { Lack of } \\
\text { Fit }\end{array}$ & 0.2164 & 16 & 0.0135 & 0.5903 & 0.8069 & & & & \\
\hline $\begin{array}{l}\text { Pure } \\
\text { Error }\end{array}$ & 0.1145 & 5 & 0.0229 & & & & & & \\
\hline $\begin{array}{l}\text { Corrected } \\
\text { Total }\end{array}$ & 1.65 & 29 & & & & & & & \\
\hline
\end{tabular}

Table 6. Optimization and validation results of canola oil deodorization parameters

\begin{tabular}{llll}
\hline Optimum parameter levels & Optimum parameter levels & Optimum parameter levels & Optimum parameter \\
\hline Temperature $\left({ }^{\circ} \mathrm{C}\right)$ & Pressure $(\mathrm{mBar})$ & Stripping Steam $(\mathrm{gr} / \mathrm{min})$ & Time $(\mathrm{min})$ \\
228.8 & 1.4 & 1.25 & 80 \\
Results of validation trials & Results of validation trials & Results of validation trials & Results of validation \\
Relative error $(\%)$ & Relative error $(\%)$ & Relative error $(\%)$ & Relative error $(\%)$ \\
\hline
\end{tabular}

Table 7. Reaction rates (k) for degradation of cis-C18:3 and formation of tr-C18:3.

\begin{tabular}{llll}
\hline & Cis-linolenic acid (cis-C18:3) & Cis-linolenic acid (cis-C18:3) & Cis-linolenic acid (cis-C18 \\
\hline Temperature $\left({ }^{\circ} \mathbf{C}\right)$ & $\mathbf{R}^{\mathbf{2}}$ & $\mathbf{k}($ cis-C18:3)* & $\mathbf{y}$ intercept \\
220 & 0.76 & 0.0032 & 6.29 \\
225 & 0.86 & 0.0049 & 6.1725 \\
230 & 0.70 & 0.0172 & 7.155 \\
\hline
\end{tabular}

${ }^{*} \mathrm{k}$ values are in $\min ^{-1}$

\section{Figure Legends}

Figure 1. FFA model graphs and 3-D response surfaces. a) distribution of actual and predicted values of FFA model, b) Cook's distance plot for FFA model, c) Response surface of FFA model for temperature versus pressure, d) Response surface of FFA model for temperature versus stripping steam rate.

Figure 2. OSI model graphs and 3-D response surfaces. a) Distribution of actual and predicted values of OSI model, b) Cook's distance plot for OSI model, c) Response surface of OSI model for temperature versus stripping steam rate, d) Response surface of OSI model for time versus pressure.

Figure 3. tr-C18:3 fatty acid model graphs and 3-D response surfaces. a) Distribution of actual and predicted values, b) Cook's distance plot of tr-C18:3 fatty acid model, c) Response surface of tr-C18:3 fatty acid model for time versus temperature 
Figure 4. cis-C18:3 fatty acid model graphs and 3-D response surfaces. a) Distribution of actual and predicted values, b) Cook's distance plot of cis-C18:3 fatty acid model, c) Response surface of cis-C18:3 fatty acid model for time versus temperature, d) Response surface of cis-C18:3 fatty acid model for temperature versus pressure.

Figure 5. PUFA model graphs and 3-D response surfaces. a) Distribution of actual and predicted values, b) Cook's distance plot of PUFA model, c) Response surface of PUFA model for time versus temperature

Figure 6 . The change in $\mathrm{k}$ of cis-C18:3 and tr-C18:3 with respect to deodorization temperature according to Arrhenius' equation.

\section{Hosted file}

figure1.docx available at https://authorea.com/users/302053/articles/432003-multipurposeoptimization-of-canola-oil-deodorization-parameters-and-evaluation-of-linolenic-acidisomerization-kinetics-during-pilot-scale-deodorization

\section{Hosted file}

figure2.docx available at https://authorea.com/users/302053/articles/432003-multipurposeoptimization-of-canola-oil-deodorization-parameters-and-evaluation-of-linolenic-acidisomerization-kinetics-during-pilot-scale-deodorization

\section{Hosted file}

figure3.docx available at https://authorea.com/users/302053/articles/432003-multipurposeoptimization-of-canola-oil-deodorization-parameters-and-evaluation-of-linolenic-acidisomerization-kinetics-during-pilot-scale-deodorization

\section{Hosted file}

figure4.docx available at https://authorea.com/users/302053/articles/432003-multipurposeoptimization-of-canola-oil-deodorization-parameters-and-evaluation-of-linolenic-acidisomerization-kinetics-during-pilot-scale-deodorization

\section{Hosted file}

figure5.docx available at https://authorea.com/users/302053/articles/432003-multipurposeoptimization-of-canola-oil-deodorization-parameters-and-evaluation-of-linolenic-acidisomerization-kinetics-during-pilot-scale-deodorization

\section{Hosted file}

figure6.docx available at https://authorea.com/users/302053/articles/432003-multipurposeoptimization-of-canola-oil-deodorization-parameters-and-evaluation-of-linolenic-acidisomerization-kinetics-during-pilot-scale-deodorization 